\title{
Increased Routing Algorithm for Mobile AdHoc Networks
}

\author{
R.Velvizhi, D.Jaya Priya, D.Vimala, I.Mary Linda
}

\begin{abstract}
A Mobile Ad-hoc Network (MANET) is an accumulation of portable hubs which impart over proportion. These systems have an essential preferred standpoint; they don't require any current foundation or focal organization. Portable specially appointed systems are appropriate for transitory correspondence joins. One of the significant issues in MANET is steering because of the versatility of the hubs. Directing means the demonstration of moving data over a web work from a source to a goal. The Enhanced Ant Routing Algorithm (EARA) depends on subterranean insect calculations. This calculation is enlivened from the insect states life. Forward bundles are utilized to gather data about the system and in reverse parcels are utilized to refresh the directing data in the hubs. EARA has two stages course disclosure and course support and furthermore utilities the idea of backtracking when the parcels are achieves goal hub. Re-enactment comes about accomplish better parcel conveyance proportion and lessen the normal end-to-end defer as contrast with its partner
\end{abstract}

\section{Index Terms: MANET,EARA,Framework}

\section{INTRODUCTION}

Systems administration is the act of connecting various registering gadgets together with a specific end goal to share assets. These assets can be printers, CDs, documents, or even electronic interchanges, for example, messages and texts. These systems can be made utilizing a few distinct strategies, for example, links, phone lines, satellites, radio waves, and infrared pillars. Without the[1],[3],[5]capacity to arrange, organizations, government offices, and schools would be not able work as effectively as they do today. The capacity for an office or school to associate many PCs to a solitary printer is an apparently basic, yet to a great degree valuable ability. Maybe significantly more profitable is the capacity to get to similar information documents from different PCs all through a building. This is unfathomably helpful for

Revised Manuscript Received on July 22, 2019

R.Velvizhi., Department of Computer Science and Engineering, Bharath Institute of Higher education and research, Chennai, India

D.Jaya Priya, Department of Computer Science and Engineering, Bharath Institute of Higher education and research, Chennai, India

D.Vimala, Department of Computer Science and Engineering, Bharath Institute of Higher education and research, Chennai, India

I.Mary Linda, Department of Computer Science and Engineering, Bharath Institute of Higher education and research, Chennai, India organizations that may have documents that require access by various representatives day by day. By using organizing, those same documents could be made accessible to a few representatives on partitioned PCs at the same time, enhancing proficiency. [38],[40]

A Mobile impromptu system is an accumulation of portable hubs sharing a remote channel with no brought together control or built up correspondence spine. MANET has dynamic topology and every portable hub has restricted assets, for example, battery, preparing power and on-board memory. A MANET have a colossal number of conceivable applications like arranged systems, crisis administrations, business and inhabitant situations, home and wander organizing, instruction, movement, sensor systems, structure mindful adjusting and scope augmentation. MANET hubs are regularly recognized by their constrained power, preparing and memory assets and high degree o versatility. In such systems, the remote hubs may powerfully enter the system and in addition leave the system. Because of the constrained transmission scope of remote system hubs, numerous desires are normally required for a hub to trade data with some other hub in the system. [2 ],[ 4],[6]

\section{A. Steering in Mobile Ad-Hoc Networks}

Steering is the way toward choosing ways in a system along which is to send information parcels. An impromptu steering convention is a tradition, or standard, that controls how hubs choose which approach to course bundles between processing gadgets in a versatile specially appointed system. [7],[ 9] ,[11]

\section{B. Steering Types}

There are chiefly two kinds of Routing specifically Static Routing and Dynamic Routing. [8],[ 10], ,12]

\section{Static Routing}

A static course is a physically composed course on your switch. Static courses are generally utilized in minor systems. [37],[39],[41]

For systems that have a great many courses, static courses are not appropriate, since you would need to design each course autonomously. A static steering in the sense when we physically include every single conceivable course in every switch's directing table. [13], [15] , [17]

\section{Dynamic Routing}

This is a keen method for directing. In this technique overseer design switch with a steering convention such a path, to the point that the convention 
finds about different switches and its courses (Routers trade courses). Indeed, even another system included or evacuated switch refresh their directing table each other. [14],[ 16], [18]

\section{EXISTING METHODOLOGY}

The current frameworks subterranean insect state based directing calculation is exceptionally versatile, proficient and adaptable. In this plan of the calculation was to diminish the overhead to rout. Look at the execution of insect steering calculations with other directing conventions. [19],[21],[23]

\section{PROPOSED METHODOLOGY}

Insect Routing Algorithm is a populace based met heuristic that can be utilized to discover estimated answers for troublesome enhancement issues. An arrangement of [31],[33],[35]programming specialists called simulated ants scan for good answers for a given improvement issue. To apply ARA, the enhancement issue is changed into the issue of finding the best way on a weighted diagram. [20],[22], [24]

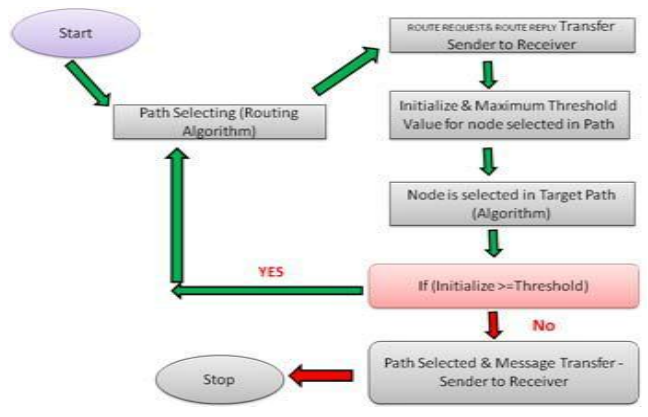

\section{FIG:1 METHODOLOGY}

\section{A. Course Maintenance}

The second period of the directing calculation is called course upkeep. This stage is in charge of the upkeep of the courses amid the correspondence. ARA does not require any unique bundles for that reason. Once the FANT and BANT have set up the pheromone tracks for the source and goal hubs consistent information parcels are utilized to keep up the way.

\section{B. Course Failure Handling}

The third and last period of EARA handles steering disappointments which are particularly caused by hub portability and are in this way extremely basic in versatile specially appointed systems. The present execution of EARA accept IEEE 802.15.4 on the MAC layer. This empowers ARA to perceive a course disappointment through a missing affirmation on the MAC layer. On the off chance that a hub gets a ROUTE_ERROR message for a specific connection, it initially deactivates this connection by setting the pheromone incentive to 0. [25],[27],[29]

\section{TESTS AND RESULTS}

\section{A. Simulation Model}

The system recreation are actualized utilizing the NS-2.23 re-enactment apparatus The Network Simulator NS-2.23 is a discrete occasion test system, which implies it mimics such occasions as sending, accepting sending and dropping bundles. For recreation Scenario and system topology creation it utilizes OTCL (Object Tool Command Language). To make new questions, conventions and directing calculation or to adjust them in NS-2.23.

\section{B. Execution Metrics}

The proportion of the information bundles conveyed to the goals to those created by the sources. It determines the parcel misfortune rate, which restricts the most extreme throughput of the system. By considering area data likewise accomplishes higher parcel conveyance proportion. [32],[34],[36]

\section{CONCLUSION}

In this paper, another half and half technique for way arranging of EARA is created and tried exceptionally well. It utilizes EARA as worldwide way arranging calculation and nearby organizer technique. We likewise misuse pheromone produced by EARA as worldwide data to direct the bounce to neighbourhood least. From the recreation comes about, we can see that by blending EARA calculation, worldwide ideal and constant hindrance shirking can be both fulfilled. This proposed directing system can be advanced to help sight and sound correspondences in versatile specially appointed systems in light of Ant Colony structure. The difficulties live in impromptu systems is to discover a way between the correspondence end focuses fulfilling client's QoS necessity which should be look after consistency. EARA has two stages course revelation and course support and furthermore utilities the idea of backtracking when the bundles are achieves goal hub. [26],[28],[30]

\section{REFERENCES}

[1] Kumarave A., Rangarajan K.,Algorithm for automaton specification for exploring dynamic labyrinths,Indian Journal of Science and Technology,V-6,I-SUPPL5,PP-4554-4559,Y-2013

[2] P. Kavitha, S. Prabakaran "A Novel Hybrid Segmentation Method with Particle Swarm Optimization and Fuzzy C-Mean Based On Partitioning the Image for Detecting Lung Cancer" International Journal of Engineering and Advanced Technology (IJEAT) ISSN: 2249-8958, Volume-8 Issue-5, June 2019

[3] Kumaravel A., Meetei O.N.,An application of non-uniform cellular automata for efficient cryptography,2013 IEEE Conference on Information and Communication Technologies, ICT 2013,V-,I-,PP-1200-1205,Y-2013

[4] Kumarave A., Rangarajan K.,Routing alogrithm over semi-regular tessellations,2013 IEEE Conference on Information and Communication Technologies, ICT 2013,V-,I-,PP-1180-1184,Y-2013

[5] P. Kavitha, S. Prabakaran "Designing a Feature Vector for Statistica Texture Analysis of Brain Tumor" International Journal of Engineering and Advanced Technology (IJEAT) ISSN: 2249-8958, Volume-8 Issue-5, June 2019

[6] Dutta P., Kumaravel A.,A novel approach to trust based identification of leaders in social networks,Indian Journal

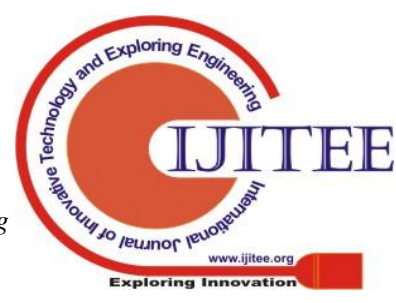


of Science and Technology,V-9,I-10,PP--,Y-2016

[7] Kumaravel A., Dutta P.,Application of Pca for context selection for collaborative filtering,Middle - East Journal of Scientific Research,V-20,I-1,PP-88-93,Y-2014

[8] Kumaravel A., Rangarajan K.,Constructing an automaton for exploring dynamic labyrinths,2012 International Conference on Radar, Communication and Computing, ICRCC 2012,V-,I-,PP-161-165,Y-2012

[9] P. Kavitha, S. Prabakaran "Adaptive Bilateral Filter for Multi-Resolution in Brain Tumor Recognition" International Journal of Innovative Technology and Exploring Engineering (IJITEE) ISSN: 2278-3075, Volume-8 Issue-8 June, 2019

[10] Kumaravel A.,Comparison of two multi-classification approaches for detecting network attacks, World Applied Sciences Journal,V-27,I-11,PP-1461-1465,Y-2013

[11] Tariq J., Kumaravel A.,Construction of cellular automata over hexagonal and triangular tessellations for path planning of multi-robots,2016 IEEE International Conference on Computational Intelligence and Computing Research, ICCIC 2016,V-,I-,PP--,Y-2017

[12] Sudha M., Kumaravel A.,Analysis and measurement of wave guides using poisson method,Indonesian Journal of Electrical Engineering and Computer Science,V-8,I-2,PP-546-548,Y-2017

[13] Ayyappan G., Nalini C., Kumaravel A.,Various approaches of knowledge transfer in academic social network,International Journal of Engineering and Technology,V-,I-,PP-2791-2794,Y-2017

[14] Kaliyamurthie, K.P., Sivaraman, K., Ramesh, S. Imposing patient data privacy in wireless medical sensor networks through homomorphic cryptosystems 2016, Journal of Chemical and Pharmaceutical Sciences 92 .

[15] Kaliyamurthie, K.P., Balasubramanian, P.C. An approach to multi secure to historical malformed documents using integer ripple transfiguration 2016 Journal of Chemical and Pharmaceutical Sciences 92 .

[16] A.Sangeetha,C.Nalini,"Semantic Ranking based on keywords extractions in the web", International Journal of Engineering \& Technology, 7 (2.6) (2018) 290-292

[17] S.V.GayathiriDevi,C.Nalini,N.Kumar,"An efficient software verification using multi-layered software verification too "International Journal of Engineering \& Technology, 7(2.21)2018 454-457

[18] C.Nalini,ShwtambariKharabe,"A Comparative Study On Different Techniques Used For Finger - Vein Authentication", International Journal Of Pure And Applied Mathematics, Volume 116 No. 82017 , 327-333, Issn: 1314-3395

[19] M.S. Vivekanandan and Dr. C. Rajabhushanam, "Enabling Privacy Protection and Content Assurance in Geo-Social Networks", International Journal of Innovative Research in Management, Engineering and Technology, Vol 3, Issue 4, pp. 49-55, April 2018.

[20] Dr. C. Rajabhushanam, V. Karthik, and G. Vivek, "Elasticity in Cloud Computing", International Journal of Innovative Research in Management, Engineering and Technology, Vol 3, Issue 4, pp. 104-111, April 2018.

[21] K. Rangaswamy and Dr. C. Rajabhushanamc, "CCN-Based Congestion Control Mechanism In Dynamic Networks", International Journal of Innovative Research in Management, Engineering and Technology, Vol 3, Issue 4, pp. 117-119, April 2018.

[22] Kavitha, R., Nedunchelian, R., "Domain-specific Search engine optimization using healthcare ontology and a neural network backpropagation approach", 2017, Research Journal of Biotechnology, Special Issue 2:157-166

[23] Kavitha, G., Kavitha, R., "An analysis to improve throughput of high-power hubs in mobile ad hoc network" , 2016, Journal of Chemical and Pharmaceutical Sciences, Vol-9, Issue-2: 361-363

[24] Kavitha, G., Kavitha, R., "Dipping interference to supplement throughput in MANET", 2016, Journal of Chemical and Pharmaceutical Sciences, Vol-9, Issue-2: 357-360

[25] Michael, G., Chandrasekar, A.,'Leader election based malicious detection and response system in MANET using mechanism design approach", Journal of Chemical and Pharmaceutical Sciences(JCPS) Volume 9 Issue 2, April - June 2016

[26] Michael, G., Chandrasekar, A.,'Modeling of detection of camouflaging worm using epidemic dynamic model and power spectral density", Journal of Chemical and Pharmaceutical Sciences(JCPS) Volume 9 Issue 2, April - June 2016.

[27] Pothumani, S., Sriram, M., Sridhar, J., Arul Selvan, G., Secure mobile agents communication on intranet,Journal of Chemical and Pharmaceutical Sciences, volume 9, Issue 3, Pg No S32-S35, 2016

[28] Pothumani, S., Sriram, M., Sridhar, Various schemes for database encryption-a survey, Journal of Chemical and Pharmaceutical Sciences, volume 9, Issue 3, Pg NoS103-S106, 2016
[29] Pothumani, S., Sriram, M., Sridhar, A novel economic framework for cloud and grid computing, Journal of Chemical and Pharmaceutical Sciences, volume 9, Issue 3, Pg No S29-S31, 2016

[30] Priya, N., Sridhar, J., Sriram, M. "Ecommerce Transaction Security Challenges and Prevention Methods- New Approach” 2016 ,Journal of Chemical and Pharmaceutical Sciences, JCPS Volume 9 Issue 3.page no:S66-S68

[31] Priya, N.,Sridhar,J.,Sriram, M."Vehicular cloud computing security issues and solutions" Journal of Chemical and Pharmaceutical Sciences(JCPS) Volume 9 Issue 2, April - June 2016

[32] Priya, N., Sridhar, J., Sriram, M. "Mobile large data storage security in cloud computing environment-a new approach" JCPS Volume 9 Issue 2. April - June 2016

[33] Anuradha.C, Khanna.V, "Improving network performance and security in WSN using decentralized hypothesis testing "Journal of Chemical and Pharmaceutical Sciences(JCPS) Volume 9 Issue 2, April - June 2016

[34] Anuradha.C, Khanna.V, "A novel gsm based control for e-devices" Journal of Chemical and Pharmaceutical Sciences(JCPS) Volume 9 Issue 2, April - June 2016

[35] Anuradha.C, Khanna.V, "Secured privacy preserving sharing and data integration in mobile web environments " Journal of Chemical and Pharmaceutical Sciences(JCPS) Volume 9 Issue 2, April - June 2016.

[36] Sundarraj, B., Kaliyamurthie, K.P. Social network analysis for decisive the ultimate classification from the ensemble to boost accuracy rates 2016 International Journal of Pharmacy and Technology 8

[37] Sundarraj, B., Kaliyamurthie, K.P. A content-based spam filtering approach victimisation artificial neural networks 2016 International Journal of Pharmacy and Technology $8 \quad 3$.

[38] Sundarraj, B., Kaliyamurthie, K.P. Remote sensing imaging for satellite image segmentation 2016 International Journal of Pharmacy and Technology $8 \quad 3$.

[39] Sivaraman, K., Senthil, M. Intuitive driver proxy control using artificial intelligence 2016 International Journal of Pharmacy and Technology 84.

[40] Sivaraman, K., Kaliyamurthie, K.P. Cloud computing in mobile technology 2016 Journal of Chemical and Pharmaceutical Sciences 92.

[41] Sivaraman, K., Khanna, V. Implementation of an extension for browser to detect vulnerable elements on web pages and avoid click jacking 2016 Journal of Chemical and Pharmaceutical Sciences 92 .

\section{AUTHORS PROFILE}

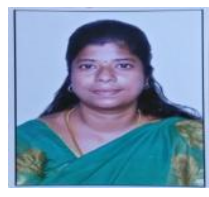

R.Velvizhi,,Assistant Professor, Department of Computer Science \& Engineering, Bharath Institute of Higher Education and Research, Chennai, India

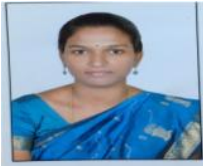

D.JayaPriya, Assistant Professor, Department of Computer Science \& Engineering, Bharath Institute of Higher Education and Research, Chennai, India

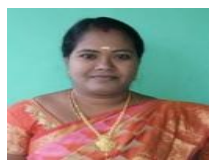

D.Vimala, Assistant Professor, Department of Computer Science \& Engineering, Bharath Institute of Higher Education and Research, Chennai, India

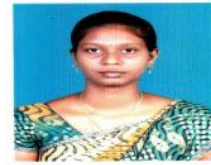

I.Mary Linda, Student, Department of Computer Science \& Engineering, Bharath Institute of Higher Education and Research, Chennai, India 